\title{
Bases teóricas y aplicación clínica de las proteínas morfogenéticas óseas en cirugía maxilofacial
}

\author{
Base theories and the clinical application of bone morphogenetic proteins in \\ maxillofacial surgery
}

\section{C.M. Ardila Medina}

Resumen: Uno de los grandes avances en la neoformación ósea ha sido la identificación de factores de crecimiento importantes para ella como son las proteinas morfogenéticas óseas (PMO) que regulan la diferenciación ósea y cartilaginosa in vivo. La depuración, clonación genética y expresión de las PMO han establecido las bases para el análisis celular y molecular del desarrollo y la regeneración ósea. El estudio genético de las PMO señala que son esenciales para la función normal animal y en la osteogénesis postfetal es importante en el desarrollo embrionario orgánico, esquelético y de los tejidos dentales y craneofaciales. La disponibilidad de las PMO proporciona retos y oportunidades para mejorar los conocimientos que regulan la regeneración ósea con el fin de optimizar los resultados en el paciente.

Palabras clave: Proteína morfogenética ósea; Regeneración ósea.

Recibido: 29.10.2008

Aceptado: 11.05 .2009
Abstract: One of the fundamental advances in bone neoformation has been the identification of important growth factors like the bone morphogenetic proteins that regulate live cartilage and bone differentiation. The cleansing, genetic cloning and expression of recombinant human bone morphogenetic proteins (BMP) have laid the basis for cellular and molecular analysis of bone development and regeneration. The genetic study of the BMPs indicates that they are essential to the normal development and function of animals. BMP post-natal bone development is also very important in embryonic organic, skeletal, craniofacial and dental tissue development. The availability of BMPs provides several challenges and opportunities to improve insights into the mechanisms that regulate the regeneration of bone for optimal outcome in the patient.

Key words: Bone morphogenetic proteins; Bone regeneration.
Profesor Asistente Universidad de Antioquia. Presidente Sociedad Colombiana de Periodoncia y Oseointegración/Regional Antioquia. Antioquia, Colombia

\section{Correspondencia:}

CM Ardila Medina

Carrera 47 No 20 sur 46 Envigado

Antioquia, Colombia 57(4) 3348122

Email: cmartin@odontologia.udea.edu.co 


\section{Introducción}

El desarrollo de las proteínas morfogenéticas óseas (PMO) ha ofrecido una alternativa al tradicional injerto óseo, el cual ha sido el estándar de oro para la reconstrucción oral y maxilofacial. Las PMO han sido usadas exitosamente en primates para restaurar mandíbulas hemisectadas y grandes defectos óseos de tamaño crítico, 1,2 para la reparación de fisuras alveolares, ${ }^{3}$ e inducción de la formación ósea en senos maxilares previa a la colocación de implantes. ${ }^{4}$ La aplicación clínica de las PMO ha incluido la reparación de defectos óseos faciales, alveolares, mandibulares y maxilares. ${ }^{5}$

El propósito de esta revisión es presentar una visión concreta sobre las proteinas morfogenéticas óseas y su potencialidad en la iniciación y promoción de la osteogénesis y su aplicación en los procesos regenerativos. Las investigaciones acerca de los iniciadores moleculares de diferenciación ósea y cartilaginosa han identificado un grupo entero de proteinas morfogenéticas óseas que ejercen un efecto regulador.

\section{Proteinas morfogenéticas y su función en la iniciación de la formación ósea}

El modelo de desarrollo postfetal óseo inducido por la matriz extracelular del hueso desmineralizado ha mostrado expectativas importantes en materia de investigación. La implantación intramuscular o subcutánea de matriz ósea desmineralizada genera diferenciación local del hueso endocondral. ${ }^{6}$ La respuesta tisular producida por esta implantación es similar a la presentada en el desarrollo óseo embriológico, ${ }^{6}$ sin embargo, a diferencia del crecimiento epifíseo, donde se observa una contínua diferenciación ósea y cartilaginosa, en el modelo de matriz ósea inducida se evidencia un solo ciclo de formación endocondral. ${ }^{6}$

Ha sido dificil la identificación de proteinas osteogénicas en la matriz ósea debido a que pequeñas cantidades de ellas se adhieren fuertemente a componentes orgánicos e inorgánicos de la matriz ósea extracelular. La existencia de proteinas morfogenéticas óseas ha sido confirmada ${ }^{6}$ debido a que la matriz ósea desmineralizada puede ser disociativamente extraida e inactivada con agentes caotrópicos (4 M guanidina- $\mathrm{HCL}$ ) y osteogénicamente restaurada por reconstituyentes que inactivan residuos (matriz insoluble de colágeno) con fracciones de proteinas solubilizadas. ${ }^{6}$ Se debe destacar, que indiferente de su solubilidad o no, la matriz colágena se activa y una combinación de las dos formas restaura la actividad osteoinductiva, en un bioensayo extra esquelético en roedores. ${ }^{7}$ Esta reconstitución operacional de la señal soluble con un substrato insoluble ha sido el punto clave experimental que ha proporcionado bioensayos auténticos para la diferenciación de cartílago y hueso. ${ }^{7}$ Este bioensayo funcional proporciona el punto de partida para la depuración de las proteinas morfogenéticas óseas, que fueron evaluadas por clonación molecular y por expresión de proteinas humanas recombinantes. ${ }^{8}$ Una de las proteinas morfogenéticas óseas, la osteogenina, se aisló de una matriz ósea bovina por cromatografía de afinidad a la heparina y fue purificada por una solución electroendosmótica después de electroforesis. ${ }^{8}$ La secuencia de aminoácidos de los péptidos de la osteogenina revelaron una estructura única primaria, idéntica a

\section{Intoduction}

The development of the bone morphogenetic proteins has allowed for an alternative to the traditional bone graft, which has been the golden standard for oral and maxillofacial reconstruction. The BMPs have been successfully used in primates to restore bisected mandibles and critical bone defects, 1,2 repair alveolar fissures, ${ }^{3}$ and induce bone formation in the maxillary sinus before implant placement. ${ }^{4}$ The clinical application of the BMP includes repairing facial, alveolar, and mandible bone defects. ${ }^{5}$

The purpose of this review is to present a clear look at bone morphogenetic proteins and their potential in the initiation and promotion of osteogenesis and how they can be applied in the regeneration process. Investigations regarding the molecular indicators of bone and cartilage differentiation have identified an entire group of bone morphogenetic proteins that have a regulating effect.

\section{Morphogenetic proteins and their role in initiating bone formation}

The post-natal bone development model induced by the extracellular matrix of demineralized bone has provided important expectations in material investigation. Muscular and subcutaneous implants of the demineralized bone matrix generate local differentiation in the endochondral bone. ${ }^{6}$ The tissue created by this implant is similar to the one seen in the embryological bone development. However, unlike the epispheo growth where there is continual bone and cartilage differentiation, in induced bone matrix model there is only one endochondral, 6 formation cycle.

Due to the small quantity of osteogenic proteins that strongly attach to the organic and inorganic components of the extracellular bone matrix, it has been difficult to identify these bone matrix proteins. The existence of bone morphogenetic proteins was confirmed 6 because the demineralized bone matrix can be dissociatively extracted and deactivated with agents such as $4 M$ guanidine HCL. They can be osteogenetically restored with reconstituents that deactivate residues (insoluble collagen matrix) with parts of soluble proteins6. It should be mentioned that regardless of its solubility, the collagen matrix activates and a combination of the two forms restores osteogenic activity in an extra skeletal bio-assay in rodents.7 This bio-assay serves as a starting point for the depurification of bone morphogenetic proteins which were evaluated by molecular cloning and recombinant human protein expression. ${ }^{8}$

One of the bone morphogenetic proteins, the osteogenin, isolated itself from a bovine bone matrix through affinity to heparin chromatography. After electrophoresis it was purified by a electroendosmosys. ${ }^{8}$ The amino acid sequence of the peptides of the osteogenin revealed a primary structure identical to the sequence of amino acids found in the DNA clones of the bone morphogenetic protein BMP-3. ${ }^{8}$ Later, the osteogenin was isolated y purified 
la secuencia de aminoácidos observada a partir de los clones de ADN de la proteina morfogenética ósea PMO-3.8 Posteriormente, la osteogenina fue aislada y purificada de la matriz ósea de un mandril. Otras proteinas osteogénicas como la PMO-2 y la PMO-4 han sido aisladas, reconocidas y clonadas gracias a la identificación por medio de clones moleculares humanos. ${ }^{9}$ Las $\mathrm{PMO}$ nativas y recombinante humana (rh) inducen la formación ósea local endocondral cuando son reconstituidas con colágeno insoluble de la matriz ósea, obtenida del residuo inactivo después de la extracción disociativa de la matriz ósea con $4 \mathrm{M}$ guanidinaHCL. 8,9

Las PMO muestran secuencias homólogas con miembros de los factores de crecimiento Beta transformantes (TGF-Beta), ${ }^{7}$ distribuidas ampliamente en vertebrados e invertebrados.4, 5 PMO-2, -3, $4,-5-6,-7$ y -8 , son sintetizados como precursores de cadenas polipeptídicas con una región terminal de cientos de aminoácidos y terminales carboxilos. 7,9 Las proteinas maduras son procesadas desde los precursores en los carboxilos terminales.

La sorprendente conservación estructural de las PMO aumenta la posibilidad de que dominen el desarrollo crítico y la función regulatoria no solamente del cartilago y el hueso, ya que existen investigaciones que indican que además de la osteogénesis posfetal, la osteogenina (PMO-3) puede influir en la esqueletogénesis embriológica. ${ }^{6}$ Además, los distintos patrones espaciales de PMO-2, PMO-3, PMO-4 y PMO-6 mRNAs, sugieren que también están involucradas en eventos relacionados con la inducción ósea que controlan el patrón de formación ósea durante el desarrollo embrionario. 4,7 PMO-7 se expresa en niveles altos en el riñón, aumentando las posibilidades de que cumpla una función endocrina. ${ }^{1}$ PMO-7 también se expresa en el cerebro, sugiriendo una posible actividad en el desarrollo del sistema nervioso central. ${ }^{1,2}$ PMO-3 se expresa principalmente en los pulmones, sugiriendo una participación en la homeóstasis tisular esquelética de una manera endocrina, como se propone en el caso del riñon. ${ }^{1,2}$ PMO-2 y PO-2 mRNAs no han sido detectadas en órganos adultos. ${ }^{10}$

En la tabla 1 se presentan las PMO que generan inducción ósea y cartilaginosa.

\section{Proteinas Morfogenéticas Óseas y Regeneración}

La interacción de las proteínas morfogenéticas óseas con las macromoléculas de la matriz extracelular, ha permitido la formulación de nuevos conceptos acerca de su potencial regulatorio en la osteogénesis. ${ }^{3,4}$ La formación ósea por inducción ha sido demostrada debido a la actividad biológica de las PMO rh y naturales en sitios extraesqueletales de primates. ${ }^{3,6,8,9}$ Importantes estudios han demostrado que la osteogenina puede ser usada para la reconstrucción de la arquitectura de la médula ósea en defectos óseos en mandriles. ${ }^{11}$ from the bone matrix of a baboon. Other osteogenin proteins like BMP-2 and BMP4 have been isolated, recognized and cloned thanks to their identification via human molecular clones. ${ }^{9}$ Insoluble collagen from the bone matrix is obtained from the inactive residue after the dissociative extraction from the bone matrix using $4 M$ guanidine-HCL. ${ }^{8,9}$ The native and recombined human BMPs induce local endochondral bone formation when they are reconstituted with this insoluble collagen. The BMPs show sequences homologous to the members of the Beta transforming growth factors (TCF-Beta) ${ }^{7}$ which are amply distributed en vertebrates and invertebrates. 4,5 BMP- $2,-3,-4,-5,-6,-7$ and -8 are synthesized like polypeptide chain precursors with a terminal region of hundreds of amino acids and carboxyl terminals. 7,9 The mature proteins are processed from the precursors of the carboxyl terminals.

The surprising structural conservation of the BMPs changes the possibility that they will dominate the critical development and regulatory function not only of the cartilage and bone but also embryonic skeletal formation. ${ }^{6}$ Now that there are investigations that show that as well as postnatal osteogenesis the osteogenin (BMP-3) can influence the embryonic skeletal formation. ${ }^{4,7}$ The distinct spatial patterns of BMP-2, BMP-3, BMP-4 and BMP- 6 mRNAs suggest that they are also involved in the bone induction that controls the bone embryonic developmental formation pattern. ${ }^{1}$ BMP-7 is present in high levels in the kidney, increasing the possibilities that it carries out its endocrine function. BMP-7 is also shown in the brain, suggesting a possible involvement in the development of the central nervous system. 1,2 BMP-3 is present mainly in the lungs, which suggests it has endocrinal involvement in the skeletal tissue homeostasis, as suggested in the case of the kidney, ${ }^{1,2}$ BMP-2 and BMP-2 mRNAS have not been detected in adult organs. 10 Table 1 shows the BMP that leads to bone and cartilage induction.

\section{Bone Morphogenetic Proteins and Regeneration}

The interaction between the bone morphogenetic proteins and the macromolecules of the extracellular matrix has led to the development of new concepts concerning their regulatory potential in osteogenesis. ${ }^{3,4}$ Inducted bone formation has been witnessed due to the recombined human and natural BMP's biological activity in extra skeletal sites of primates. 3,6,8,9 Important studies have shown that osteogenesis can be used in reconstruction of the bone marrow for bone deformities in Bamboos. ${ }^{11}$ 
Es importante para aplicaciones futuras el concepto de que la inducción óptima de formación ósea depende de la acción combinada de PMO y un sustrato complementario. El compuesto del sustrato de la matriz extracelular en estado sólido, en asociación con PMO solubles, inicia la cascada de diferenciación ósea. ${ }^{3}$ La restauración de la actividad biológica después de la extracción disociativa y reconstrucción de la PMO con matriz de colágeno insoluble indica que los componentes de la matriz extracelular ósea actúan como un vehículo para la expresión funcional de las PMO.2,9 Algunas investigaciones han demostrado que el colágeno de la matriz ósea proporciona un sustrato óptimo para el reclutamiento y adhesión de células progenitoras y la posterior proliferación y diferenciación en osteoblastos.1, 2 La fundamentación de la matriz de colágeno en el desarrollo y diferenciación ha sido manifestado tempranamente, ${ }^{8}$ demostrando que la matriz de colágeno puede prevenir la difusión prematura en la implantación quirúrgica, ${ }^{2,9}$ y puede proteger la PMO de proteólisis no específica. El colágeno transportador actúa como substrato provisional hasta ser reemplazado por nuevo hueso formado.

\section{Aplicaciones clínicas}

A continuación se discutirá brevemente el uso clínico de las PMO en defectos de continuidad mandibular, aumento maxilo-mandibular preprotésico, trauma maxilofacial y reconstrucción de fisuras alveolares.

Defectos de continuidad mandibular: son defectos secundarios a la resección de tumores que resultan en una morbilidad significante sino son quirúrgicamente reconstruidos, convirtiendo de esta manera a los injertos autógenos en una alternativa importante para dicha reconstrucción. Toriumi y colaboradores, emplearon un modelo canino para estudiar PMO-2 para estimular crecimiento en un defecto de continuidad mandibular, ${ }^{12}$ encontrando que el $68 \%$ del defecto fue reemplazado por hueso mineralizado. Boyne encontró que la PMO-2 fue un inductor efectivo de la regeneración osea en primates con defectos óseos de tamaño crítico. ${ }^{1}$ En 2004, Warnke y colaboradores, usaron PMO-7 y bloques de hueso mineralizado (xenoinjertos), para crear injertos vascularizados en humanos, ${ }^{13}$ hallando remodelación ósea y mineralización. El desarrollo de procedimientos de reconstrucción efectivos utilizando factores osteoinductivos sin necesidad de injertos óseos, tendría un fuerte impacto sobre las cirugías reconstructivas de cabeza y cuello.

Aumento preprotésico maxilomandibular: este tipo de aumentos usando injertos óseos y sustitutos óseos son muy frecuentes. Los procedimientos más comunmente empleados incluyen aumento de rebordes y elevación de seno maxilar. Jovanovic y colaboradores, realizaron un estudio histológico en un modelo animal en el que se llevo a cabo un aumento de reborde alveolar. No encontraron diferencias significativas entre los injertos con PMO-2 osteoinducidos, comparado con el hueso residente, estableciendo que la PMO-2 permite la instalación, oseointegración y carga funcional a largo plazo en implantes dentales ubicados en perros. ${ }^{14}$ Boyne y colaboradores, publicaron recientemente los resultados de un estudio multicéntrico en el que se evaluaba PMOrh en el seno maxilar, ${ }^{4}$ concluyendo que la PMO inducía hueso de una manera pre-
The idea that optimal induction of bone formation depends on the combined action of the BMP and the complimentary substrate is an important one for future projects. When in a solid state, the substrate compound of the extracellular matrix, in association with soluble BMPs, starts the cascade of bone differentiation. ${ }^{3}$ After dissociative extraction and reconstruction of the BMP with an insoluble collagen matrix biological activity is restored. This indicates that the components of the extracellular bone matrix act as a vehicle for the functional expression of the bone morphogenetic proteins. 2,9 Some investigations have illustrated that the collagen bone matrix provides an optimal substrate for the recruitment and adhesion of regenerative cells, posterior proliferation and osteoblast differentiation. ${ }^{1,2}$ The foundation of the collagen matrix in the development and differentiation was manifested early, showing that the collagen matrix can prevent the premature diffusion of the surgical implant, 2,9 as well as protect the BMP from unspecified proteolysis. The collagen transporter acts as a provisional substrate until it is replaced by new bone formation.

\section{Clinical Application}

Below the clinical use of BMP in mandible defects, preprosthethic maxillary and mandible regeneration, maxillofacial trauma and alveolar fissure reconstruction will be discussed.

Mandible continuity defects are secondary to the recession of tumours which have a high mortality when not surgically reconstructed, converting autogenetic implants into an important alternative for said reconstruction. Toriumi and collaborators, use a canine model to study BMP-2 to stimulate growth in defected mandibles. ${ }^{12}$ They found that $68 \%$ of the defects were substituted by mineralized bone. Boyne found that the BMP-2 was an effective bone regenerative inductor in primates with critical bone defects. I In 2004, Warnke et al. used BMP-7 and blocks of mineralized bone to create vascularised human bone grafts they discovered bone restoration and mineralization. ${ }^{13}$ Development of effective reconstruction procedures using bone inductive factors without the need for bone grafts would have a strong impact on reconstructive head and neck surgeries.

Preprosthethic maxillary and mandibular lift augmentation: the use of bone implants and substitutes are frequent. The most commonly used procedures are alveolar ridge raise and maxillary sinus elevation. Jovanovic and cols. did a histological study where they carried out alveolar ridge raise on an animal model. When compared with resident bone, they did not find significant differences among the implants with bone induced BMP-2. With this they concluded that the BMP2 allows for the installation, bone integration and long term "functional load" in dental implants placed in dogs. ${ }^{14}$ Boyne and cols. recently published a study which evaluated recombinant human BMP in the maxillary sinus. ${ }^{4}$ They concluded that the BMP induced bone with certainty and predictability, which is suitable for the functional load of 
decible y segura, adecuada para la carga functional de implantes endoseos en aquellos pacientes que requieren aumento del seno maxilar.

Trauma maxilofacial: algunos estudios han sido realizados con el fin de evaluar la PMO-2 en casos de trauma, demostrando su efectividad en el tratamiento de defectos segmentales completos o parciales de huesos largos. ${ }^{15,16}$ En daños severos en los que se presenta pérdida de tejidos blandos y duros, los tratamientos se enfrentan a desafios que incluye la obtención del cierrre de los tejidos blandos y la prevención de la contaminación y pérdida de la PMO-2, como en el caso de las heridas de bala, donde puede existir una significativa zona de daño necrótico, que puede requerir posterior debridamiento y reconstrucción secundaria.

Reconstrucción de fisuras alveolares: el procedimiento estándar para el tratamiento de fisuras alveolares, ha sido reportado por Boyne y Sands utilizando partículas autógenas de cresta iliaca. ${ }^{17}$ Boyne y colaboradores, compararon PMO-2 e injertos de cresta iliaca en defectos alveolares simulados en primates, ${ }^{3}$ encontrando que no existían diferencias estadísticamente significativas entre ellos. Actualmente, muchos pacientes se benefician del uso de PMO -2 para inducir formación ósea en fisuras palatinas eliminando la necesidad de intervenir un área donante. ${ }^{5}$

\section{Perspectivas de las Proteínas Morfogenéticas Oseas}

La capacidad de las Proteínas Morfogenéticas Oseas de los mamíferos para iniciar un curso programado que resulte en la inducción ósea, puede ser un proceso funcionalmente utilizado en el desarrollo embriológico, sintetizado en la osteogénesis postfetal y puede ser promisorio para la iniciación terapéutica de la formación ósea. ${ }^{18}$

Los injertos óseos han sido el estándar de oro para la reconstrucción maxilofacial. Sus ventajas, tales como altas tazas de éxito, disponibilidad de cantidades considerables, además de su biocompatibilidad, hacen del injeto autógeno la alternativa de elección en la reconstrucción ósea. Sin embargo, algunas desventajas inmersas incluyen los altos costos del procedimiento, la necesidad de un sitio donante, necesidad de hospitalización y la morbilidad postoperatoria entre otros. ${ }^{18}$

La aplicación de factores de crecimiento específicos para la osteoinducción sin necesidad de usar un injerto óseo, podría tener un tremendo impacto en la reconstrucción maxilofacial. Más de 20 PMO han sido aisladas con diferentes habilidades para aumentar la osteogenesis. Las tipo 2, 4, 7, al parecer tienen la mayor habilidad para estimular la formación ósea.

Desde una perspectiva terapéutica, es necesario enfocar las investigaciones sobre la formulación de sistemas de distribución para las PMO. Un sustrato ideal que actúe como un sistema de distribución osteogénico debe ser inorgánico, no inmunogénico y sensible para una óptima adhesión y también debe proporcionar soporte completo al colgajo mucoperióstico.

Un avance coyuntural será la identificación, aislamiento y clonación de los receptores de las proteinas óseas. La expresión de clonación de receptores de PMO será un auxilio importante para el diseño de enfoques terapéuticos que generen formación ósea. endosseous implants in those patients that need their maxillary sinus raised.

Maxillofacial Trauma: studies have been done that evaluate BMP-2 in trauma cases, showing their effectiveness in treating complete segment defects or partial long bones. 15,16 The severe pain in those that had soft and hard tissue loss led to challenges such as: procurement of soft tissue closure and contamination prevention. Another challenge was the loss of the BMP-2 in gunshot wounds, where there can be a significant necrotic pain zone which could later require debridement and secondary reconstruction.

Alveolar Fissure Reconstruction: the standard procedure for alveolar fissure treatment has been reported by Boyne and Sands. Using autogenous particles from the iliac crest ${ }^{17}$ they compared BMP-2 and iliac crest grafts in primates with alveolar defects. ${ }^{3}$ Statistically significant differences were not found. Currently many patients benefit from the use of BMP2 to induce bone formation in palatine fissures. It eliminates the need for a donor area intervention. ${ }^{5}$

\section{Bone Morphogenetic Protein Perspectives}

The ability of BMPs in mammals to start the bone formation process can be a useful procedure in embryonic development. It can also be synthesized in the post-natal bone formation. As well, it can be used to start therapeutic bone formation. ${ }^{18}$

Bone implants have been a golden standard in maxillofacial reconstruction. Their advantages include high success rates, numerous availability and biocompatibility. These advantages lead to autogenous implants being the second choice alternative. However, some not so obvious disadvantages also exist. They include, among others, the high cost of the procedure, the need for $a$ donor site, the need for hospitalization and postoperative morbidity. ${ }^{18}$

The application of specific growth factors for bone induction without the need for a bone graft could have a tremendous effect on maxillofacial reconstruction. More that 20 BMPs have been isolated with different osteogenetic augmentation abilities. Type 2, 4 and 7 appear to have the greatest ability to stimulate bone formation.

From a therapeutic perspective it is necessary to focus investigations on creating distribution systems for the BMPs. An ideal distribution system substrate should be inorganic, non immunogenic and sensitive for optimal adhesion. It should also provide complete support to the mucoperiosteal flap.

A current advance will be the identification, isolation and cloning of bone protein receptors. The ability to clone BMP receptors will be an important aid in designing a therapeutic approach that generates bone formation. 


\section{Bibliografía}

1. Boyne PJ. Application of bone morphogenic proteins in the treatment of clinical oral and maxillofacial osseous defects. J Bone Joint Surg Am 2001;83:146-50.

2. Boyne PJ, Salina S, Nakamura A, Audia F, Shabahang S. Bone regeneration using rhBMP-2 induction in hemimandibulectomy type defects of elderly subhuman primates. Cell Tissue Bank 2006;7:1-10.

3. Boyne PJ, Nath R, Nakamura A. Human recombinant BMP-2 in osseous reconstruction of simulated cleft palate defects. Br J Oral Maxillofac Surg 1998;36: 84-9.

4. Boyne PJ, Lilly LC, Marx RE, Moy PK, Nevins M, Spagnoli DB, y cols. De novo bone induction by recombinant human bone morphogenic protein-2 (rhBMP-2) in maxillary sinus floor augmentation. J Oral MaxiIlofac Surg 2005;63:1693-707.

5. Herford AS, Boyne PJ, Williams RP. Clinical applications of rhBMP-2 in maxillofacial surgery. I Calif Dent Assoc 2007;35:335-41.

6. Sampath TK, Reddi AH. Dissociative extraction and reconstitution of extracellular matrix components involved in local bone differentiation. Proc Natl Acad Sci USA 1981;78:7599-603.

7. Sampath TK. Mulhukumaran N. Reddi AH. Isolation of osteogenic an extracellular matrix-associated, bone inductic protein, by heparin aflinity chromatography. Proct Natl Acad Sci USA 1987;84:7109113.

8. Luyten FP. Cunningham NS, Ma S, Muthukumaran N, Hammonds RG, Nevins WB, y cols. Purfication and partial amino acid sequence of osteogenin, a protein initiating bone differentiation. J Biol Chem 1989;264:13377-80.

9. Sampath TK, Coughlin JE, Whelstone RM, Banach D, Corbett C, Ridge $\mathrm{RJ}$, et al. Bovine osteogenic protein is composed of dirners of' OP-I and
BMP-2A, two members of' the transforming growth factor B superfamily. J Biol Chem 1990; 265;13198-205.

10. Ozkaiynak E. Schnegelsberg PNJ. Oppermann H. Murine osteogenic protein (OP-1): high levels of mRNA in kidney. Biochem Biophys Res Commun 1991;179:116-23.

11. Ripamonti U, Ma S, Cunningham N, Yeates L, Reddi AH. Reconstruction of the bone-bone marrow organ by osteogenin, a bone morhogenetic protein, and demineralized bone matrix in calvarial defects of adult primates. Plast Reconstr Surg 1993;91:27-36.

12. Toriumi DM, Kotler HS, Luxenberg DP, Holtrop ME, Wang EA, y cols, Mandibular reconstruction with a recombinant evaluation. Arch Otolaryngol Head Neck Surg 1991;117:1101-12.

13. Warnke PH, Springer IN. Growth and transplantation of a custom vascularized bone graft in a man. Lancet 2004;364:766-70.

14. Jovanovic SA, Hunt DR. Long-term functional loading of dental implants in rhBMP-2 induced bone. A histologic study in the canine ridge augmentation model. Clin Oral Implants Res 2003;14:793-803.

15. Johnson EE, Urist MR, Finerman GA. Resistant nonunions and partial or complete segmental defects of long bones. Treatment with implants of a composite of human bone morphogenic protein (BMP) and autolyzed, antigen-extracted, allogeneic (AAA) bone. Clin Orthop Relat Res 1992;227:229-37.

16. Gerhart TN, Kirker-Head CA, Kriz MJ, Holtrop ME, Hennig GE, Hipp J, y cols, Healing of large midfemoral segmental defects in sheep using recombinant human bone morphogenic protein (BMP-2). Trans Orthop Res Soc 1991;16:172.

17. Boyne PJ, Sands NR, Combined orthodontic-surgical management of residual palato-alveolar cleft defects. Am J Orthod 1976;70:20-37.

18. Lorz P, Trujillo E. Proteínas morfogenéticas de hueso en oseointegración: revisión sistemática de literatura. Rev Fed Od Colombiana 2005;25-30. 